\title{
CREDITORS' AND THIRD PARTIES' RIGHTS IN REM UNDER EUROPEAN UNION REGULATIONS AND THE UNCITRAL LEGISLATIVE GUIDE ON INSOLVENCY LAW
}

\begin{abstract}
The purpose of this article is to present the legal position of creditors and third parties secured by rights in rem. The analysis takes into consideration the situation when the bankruptcy of a debtor is declared. The purpose of the article is to present the regulation provided in European Union regulations. According to the European Union regulations, the opening of insolvency proceedings does not affect the rights in rem of creditors or third parties belonging to the debtor which are situated within the territory of another Member State at the time of the opening of insolvency proceedings. Therefore, the question arises of whether the scale of protection of a secured creditor or of third parties' is too wide in comparison with other creditors. Moreover, it is necessary to compare the European Union provisions with regulations of an international character. The provisions of the UNCITRAL Legislative Guide on Insolvency Law constitute a point of reference for a comparative analysis of this issue.
\end{abstract}

\section{Keywords}

rights in rem - EIR - recast EIR - UNCITRAL Legislative Guide on Insolvency Law creditors

* Dr Karolina Ochocińska; https://orcid.org/0000-0002-7003-7488; e-mail: karolinaochocinska8@gmail.com. 


\section{INTRODUCTION}

Issues concerning insolvency proceedings were regulated in the European Union (EU) in Regulation 1346/2000 of the Council of 29 May 2000 on insolvency proceedings (EIR). ${ }^{1}$ Since 26th June 2017, it has been replaced by Regulation 2015/848 of the European Parliament and of the Council of 20 May 2015 on insolvency proceedings (recast EIR). ${ }^{2}$

Both legal acts establish a European framework for cross-border insolvency proceedings. It applies whenever the debtor has assets or creditors in more than one Member State. ${ }^{3}$ There is one exception to the territorial scope of these legal acts. Denmark is not taking part in the adoption of these legal acts and is not bound by them or subject to their application. ${ }^{4}$

The proper functioning of the internal market requires that crossborder insolvency proceedings should operate efficiently and effectively. ${ }^{5}$ The rationale behind the EIR and the recast EIR is to prevent forum shopping. It is necessary to avoid incentives for parties to transfer assets or judicial proceedings from one Member State to another, seeking to obtain a more favourable legal position to the detriment of the general body of creditors. ${ }^{6}$

The UE Regulations determine which court has jurisdiction to open insolvency proceedings and establish uniform rules on the applicable law. They also ensure the recognition and enforcement of the ensuing decision throughout the Union. ${ }^{7}$ Any judgment opening insolvency proceedings handed down by a court of a Member State which has jurisdiction shall be recognised in all other Member States

${ }^{1}$ OJ L 160, 30.6.2000, p. 1-18 (hereafter the 'EIR').

2 OJ L 141, 5.6.2015, p. 19-72 (hereafter the 'recast EIR').

${ }_{3}$ Report from the Commission to the European Parliament, the Council and the European Economic and Social Committee on the application of Council Regulation (EC) No 1346/2000 of 29 May 2000 on insolvency proceedings, p. 3, available at: https:// publications.europa.eu/en/publication-detail/-/publication/3cf7daf5-f82c-4b24-b14e-ef d36d814f82/language-en [last accessed 21.5.2021].

${ }^{4}$ Recital 88 of preamble recast EIR and recital 33 of preamble EIR.

${ }^{5}$ Recital 3 of preamble recast EIR and recital 2 of preamble EIR.

${ }^{6}$ Recital 5 of preamble recast EIR and recital 4 of preamble EIR.

7 Report, supra note 3, p. 3. 
from the moment that it becomes effective in the State of the opening of proceedings. ${ }^{8}$ The same rule applies to the judgments handed down by a court whose judgment concerning the opening of proceedings is recognised and which concern the course and closure of insolvency proceedings. ${ }^{9}$ For that reason, declaration of insolvency in one Member State takes effect in every other Member State.

Neither EIR nor the recast EIR harmonise substantive law on insolvency proceedings. The reason for this is the differentiation of insolvency procedures in EU Member States. ${ }^{10}$

The question of the position of secured creditors and third parties is related to the problem of applicable law. The rules governing applicable law are provided in the recast EIR. It is also beneficial to add a couple of remarks on EIR provision concerning this matter. That legal act provided the same solutions. Therefore, further considerations will include references to the commentators statements devoted to the regulation provided for in EIR. They are still valid under the recast EIR.

\section{The General Rule And the Exception}

According to article 7(1) of the recast EIR, the law applicable to insolvency proceedings and their effects shall be that of the Member State within the territory of which such proceedings are opened. Articles 8-18 recast EIR stipulate an exception to this rule. A similar regularity was provided for in the EIR. Article 4 of the EIR delivered an answer to the question of applicable law while articles 5-15 EIR contained several exceptions to this general principle. Including, inter alia, the one concerning rights in rem in article 5 EIR. ${ }^{11}$

8 Article 19(1) recast EIR and article 16(1) EIR.
9 Article 32(1) recast EIR and article 25(1) EIR.
${ }_{10}$ S. Bewick, "The EU Insolvency Regulation, Revisited", Insolvency International Review, 2015, vol. 24, p. 172-173.

11 G. McCormack, "Reforming the European Insolvency Regulation: A Legal and Policy Perspective", Journal of Private International Law, 2014, vol. 10, no. 1, p. 59; P. Smart, "Rights In Rem, Article 5 and the EC Insolvency Regulation: An English Perspective", International Insolvency Review, 2006, vol. 15, issue 1, p. 19; J. Lachner, in K. Kohutek, J. Lachner (eds.), Komentarz do rozporzadzenia nr 1346/2000 w sprawie postępowania upadłościowego, LEX/el. 2007; B. Wessels, "Rights in rem of third parties under the EU Insol- 
The regulation on exception applicable to rights in rem is as follows. The opening of insolvency proceedings shall not affect the rights in rem of creditors or third parties in respect of tangible or intangible, moveable or immoveable assets, both specific assets and collections of indefinite assets as a whole which change from time to time, belonging to the debtor which are situated within the territory of another Member State at the time of the opening of proceedings. ${ }^{12}$

It is worthwhile to pay attention to the reasons for that regulation. Rights in rem are of considerable importance for the granting of credit. ${ }^{13}$ A well-functioning credit system without adequate protection of the security attached to such credit is inconceivable. Choosing between the protection of certainty or optimizing the insolvency estate decides in essence on a company's creditworthiness, and therefore often on its ability to survive, at least in the case of a company with a weak equity base. ${ }^{14}$ For this reason, there is a particular need for a special reference diverging from the law of the opening State in the case of rights in rem. ${ }^{15}$ This very aspect imparts such commercial importance to the whole field of real security. ${ }^{16}$

There is no precise definition of rights in rem. ${ }^{17}$ The EU legislator limits itself to providing an exemplary catalogue of rights in rem. ${ }^{18}$ The rights in rem shall, in particular, mean the right to dispose of assets or have them disposed of and to obtain satisfaction from the proceeds of or income from those assets, in particular by virtue of a lien or a mortgage, ${ }^{19}$ the exclusive right to have a claim met, in particular a right guaranteed

vency Regulation", p. 2-3, available at: https://www.iiiglobal.org/sites/default/files/ media/1_Wessels_Rightsinrem.PDF [last accessed 21.5.2021].

12 Article 8(1) recast EIR and article 5(1) EIR.

${ }^{13}$ Recital 68 of preamble recast EIR and recital 25 of preamble EIR.

${ }_{14}$ T. Ingelmann, in K. Pannen (ed.), European Insolvency Regulation, De Gruyter, 2007, p. 247.

${ }^{15}$ Recital 68 of preamble recast EIR and recital 25 of preamble EIR.

${ }^{16}$ I. F. Fletcher, "The European Union Convention on Insolvency Proceedings: Choice-of-Law Provisions", Texas International Law Journal, 1998, vol. 33, p. 128-129.

17 G. McCormack, "Something Old, Something New: Recasting the European Insolvency Regulation", The Modern Law Review, 2016, vol. 79, issue 1, p. 138; J. Lachner, supra note 11; T. Ingelmann, supra note 14, p. 252.

18 J. Lachner, supra note 11.

19 Article 8(2)(a) recast EIR and article 5(2)(a) EIR. 
by a lien in respect of the claim or by assignment of the claim by way of a guarantee, ${ }^{20}$ the right to demand assets from, and/or to require restitution by, anyone having possession or use of them contrary to the wishes of the party so entitled ${ }^{21}$ and a right in rem to the beneficial use of assets. ${ }^{22}$ Moreover, the right, recorded in a public register and enforceable against third parties, based on which a right in rem may be obtained shall be considered to be a right in rem. ${ }^{23}$

Lack of defining rights in rem was a deliberate decision in order to allow the law of the state where the relevant assets are located to decide. Accordingly, the question of how a particular right held by a creditor is to be characterised must be decided under the national law which applies under the normal conflict of law rules. This would normally be the lex rei sitae. ${ }^{24}$

The assessment of whether a given right is a right in rem is made in relation to specific circumstances. Thanks to this, the regulation provided for in article 8 recast EIR is flexible. It can be applied to types of security that were unknown at the time the legislation entered into force. However, it cannot be ignored that the application of article 8 recast EIR each time requires an assessment of whether we are dealing with right in rem. This is not an automatic process. Therefore, it can raise disputes between the parties i.e. bankruptcy trustee and creditor.

Under the provisions of the EIR, it was pointed out that article 5 EIR is only applicable to rights which are in existence at the time of the opening of insolvency proceedings. In the event that these rights have been created after the opening of proceedings, article 4 EIR is fully applicable. ${ }^{25}$ By the same token time of creation of right in rem is also of the essence when it comes to application of article 8 of the recast EIR.

20 Article 8(2)(b) recast EIR and article 5(2)(b) EIR.

${ }^{21}$ Article 8(2)(c) recast EIR and article 5(2)(c) EIR.

${ }^{22}$ Article 8(2)(d) recast EIR and article 5(2)(d) EIR.

${ }^{23}$ Article 8(3) recast EIR and article 5(3) EIR.

${ }^{24}$ T. Smith, "Applicable law and carve outs: cross-border security and rights in rem", ERA Forum, 2016, vol. 16, p. 257; M. Virgos, E. Schmit, "Report on the Convention on Insolvency Proceedings", p. 73, available at: http://aei.pitt.edu/952/1/insolvency_ report_schmidt_1988.pdf [last accessed 21.5.2021]; T. Ingelmann, supra note 14, p. 253.

${ }^{25}$ B. Wessels, supra note 11, p. 3; M. Virgos, E. Schmit, supra note 24, p. 71; P. Smart, supra note 11, p. 21; T. Ingelmann, supra note 14, p. 251. 
However, the rules governing the application of article 5 EIR (present article 8 of the recast EIR) could be tricky. It cannot be excluded that the national law of a Member State contains a right, which between certain parties (e.g. between a borrower and a bank) has certain "rem" elements, but only at the moment that the holder of the right effectively pursues his right. In such situation the interpretation followed in the specific jurisdiction will prevail. ${ }^{26}$

Another essential aspect of regulation provided in article 8 of the recast EIR is the interpretation of the term "assets belonging to the debtor". The question is whether the regulation covers legal ownership or also forms of economic ownership and certain "propriety rights" in assets, which according to the governing law are attributed to the estate. The rights in rem were not strictly interpreted under the EIR. ${ }^{27}$ It speaks for a broad perception of rights in rem also under article 8 of the recast EIR. This solution seems reasonable owing to the diversity of the legal systems of the EU Member States. For this reason, the understanding of "assets belonging to the debtor" may differ from one EU Member State to another.

There is one substantial difference between the EIR and the recast EIR when it comes to rights in rem. It concerns the location of assets which is a key aspect of the application of article 8 of the recast EIR. ${ }^{28}$ Article 8 of the recast EIR and article 5 of the EIR apply only where the asset is situated within the territory of a Member State other than the one where the insolvency proceedings are commenced. When it comes to location it means physical location. ${ }^{29}$

Under the EIR a number of questions were raised as to the position in respect of certain types of assets. For example, as to shares in a company or cash in a bank account, particularly where the bank account was held with a branch located in one Member State of a bank which had its centre of main interest in a different Member State. Article 2(9) of the recast EIR introduces definitions of where assets are located. It includes

26 B. Wessels, supra note 11, p. 3.

27 Ibid., p. 3.

28 G. McCormack, "Something Old", supra note 17, p. 138; T. Smith, supra note 24, p. 257.

${ }^{29}$ B. Wessels, supra note 11, p. 6; T. Ingelmann, supra note 14, p. 251-252. 
the location of registered shares in companies, book-entry securities, cash held in bank accounts and patents, copyright and related rights. ${ }^{30}$

\section{Article 8 of the Recast Eir - Substantive LaW OR CONFLICT OF LAW RULE?}

The main problem which concerns the application of article 8 of the recast EIR arises from the interpretation of the expression "the opening of insolvency proceedings shall not affect the rights in rem of creditors". The same issue made it difficult to apply the article 5 EIR. ${ }^{31}$ As the wording "shall not affect" is not quite clear, commentators have interpreted it in four different ways. The positions of commentators on that matter are summarised in the report prepared by INSOL Europe. ${ }^{32}$ Firstly, the right in rem is limited by the lex rei sitae i.e. the law of the Member State in which the asset is situated. The right in rem will not be affected by the lex concursus of the main proceedings, but will be bound by any limitations imposed by the lex rei sitae. ${ }^{33}$

Secondly, the right in rem is limited only to the extent that the limitations of the lex rei sitae match those of the lex concursus. It means that security rights in rem are not affected to a larger extent than would be the case if local national insolvency proceedings were opened. ${ }^{34}$

Thirdly, the right in rem is limited only by the lesser limitations of either the lex rei sitae or the lex concursus. This means that the secured creditor may profit from the difference between the two regimes. ${ }^{35}$

Fourthly, the right in rem is affected by neither the lex concursus nor the lex rei sitae. This so called "hard and fast rule" or "maximalist view"

30 T. Smith, supra note 24, p. 257-258.

31 G. McCormack, "Something Old”, supra note 17, p. 138; A. Adamczyk, "Sytuacja wierzycieli zabezpieczonych rzeczowo w transgranicznym postępowaniu upadłościowym", Przegląd Prawa Handlowego, 2009, no. 5, p. 40.

${ }^{32}$ R. van Galen, M. André, D. Fritz, V. Gladel, F. van Koppen, D. Marks, N. Wouters, "Revision of the European Insolvency Regulation. Proposals by INSOL Europe", p. 51, available at: https://www.insol-europe.org/download/documents/588 [last accessed 21.5.2021].

33 Ibid., p. 51.

${ }^{34}$ Ibid., p. 51-52.

35 Ibid., p. 52. 
implies that the holder of the right in rem can exercise its rights without any exception or limitation. ${ }^{36}$

The report of INSOL Europe highlights that the fourth approach has been followed during the negotiations prior to the EIR enactment. Moreover it quotes the current "hard and fast rule" as being highly debatable, as it overprotects the secured creditor, since it may afford a stronger level of protection against the insolvency of the debtor than that which the national laws demand. On the other hand, the overprotection offered to the secured creditor can only be understood if one realises that the main aim of it is to facilitate the administration of insolvency proceedings. ${ }^{37}$ In conclusion INSOL Europe was agreed with the objection that secured creditors are overprotected as a result of the hard and fast rule. Therefore, it was suggested that exception from application of lex fori concursus should be along the lines of the second approach mentioned above. ${ }^{38}$

Unfortunately, the EU legislators did not make any changes in that area. ${ }^{39}$ The question of whether article 8 of the recast EIR is a substantive law or conflict of law rule is still valid. There is no legal answer to the scope of protection of creditors and third parties' rights in rem. It leads to uncertainty of positions of this type of creditors during insolvency proceedings, but also may cause different treatment of the same category of persons during insolvency proceedings. Depending on the way of interpretation of article 8 of the recast EIR.

At present, it seems that article 8 of the recast EIR should be understood as a provision of substantive law. Just as article 5 of the EIR article 8 of the recast EIR is a substantive law norm and not a conflict of laws rule because it is not a provision that specifies which law applies to third party in rem rights, but merely precludes the applicability of the lex fori concursus. ${ }^{40}$

This conclusion follows from the rationale behind the regulation provided for in article 8 of the recast EIR (previous article 5 of the EIR). As was pointed out, article 5(1) of the EIR must be understood as

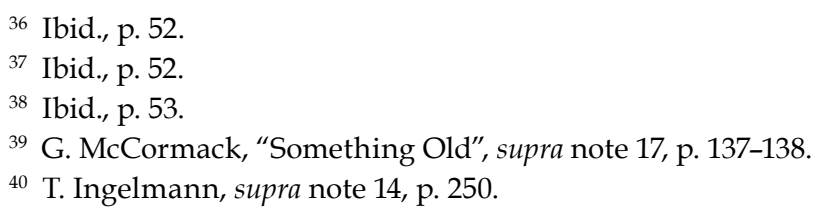


a provision which derogates from the rule of the law of the State of the opening of the proceedings. It is allows the law of the Member State on whose territory the asset concerned is situated (lex rei sitae) to be applied to the right in rem of a creditor or a third party in respect of certain assets belonging to the debtor. Protection under that article is given only to rights in rem in respect of the debtor's assets which are situated in a Member State other than the State of the opening of the insolvency proceedings at the time the proceedings are opened. Article 5 of the EIR is not a conflict-of-laws rule, but a 'negative' substantive rule, the purpose of which is to uphold rights in rem acquired before the opening of the insolvency proceedings. ${ }^{41}$

In order that a creditor may be able to assert his/her right in rem effectively, he/she must be able to exercise the right after the opening of insolvency proceedings and the particular conditions under the law of the state where the assets are located should apply rather than the law of the state of the opening of proceedings. ${ }^{42}$

\section{Case of Detrimental Legal Acts}

Last but not least, it is worth paying attention to the relation between the exception provided in article 8 of the recast EIR and the regulation of detrimental acts. According to article 8(4) of the recast EIR, paragraph 1 of that article shall not preclude actions for voidness, voidability or unenforceability as referred to in point $(\mathrm{m})$ of article $7(2)$ of the recast EIR.

Thanks to that, the rules relating to the voidness, voidability, or unenforceability of legal acts detrimental to all creditors are in general to be governed by the law of the State of the opening of proceedings. ${ }^{43}$ This means that the act by which the right in rem is created might be

${ }^{41}$ Opinion of Advocate General Szpunar delivered on 27 November 2014, Case C557/13, Hermann Lutz v. Elke Bäuerle, para. 31.

${ }^{42}$ Hermann Lutz v. Elke Bäuerle, Case C-557/13, Judgment of 16.4.2015, para. 40.

${ }^{43}$ Article 7(2)(m) recast EIR and 4(2)(m) EIR. 
subject to a challenge in the form of an action which would be governed by the law of the State of the opening of the proceedings. ${ }^{44}$

National insolvency laws typically contain rules on avoidance actions. Some of them are designed to provide sanctions against fraudulent behaviour or transactions at an undervalue, whereas others aim to enforce the principle of equal treatment of creditors by enabling the insolvency practitioner to challenge the preferential treatment of a creditor within a given "suspect period" prior to the application for, or opening of, insolvency proceedings. ${ }^{45}$

Although there is a clear corpus of transactions that are generally invalidated in nearly all Member States, the laws around the EU provide for the avoidance of various and different types of transactions. ${ }^{46}$

The transactions most frequently subject to some form of avoidance rule are preferences and transactions that might be classified as transactions at an undervalue. ${ }^{47}$ Moreover, that group includes preferences i.e. transactions which involve the debtor giving some benefit within a certain time period prior to the commencement of insolvency proceedings against the debtor, and this is to the detriment of the other creditors who do not get paid or receive any security in relation to the debts owed to them. ${ }^{48}$ An example of a detrimental act is also a transaction intended to prejudice creditors. It can be set aside by an actio Pauliana claim..$^{49}$ Most Member States also have some avoidance

${ }^{44}$ R. van Galen, M. André, D. Fritz, V. Gladel, F. van Koppen, D. Marks, N. Wouters, supra note 32, p. 53; B. Wessels, supra note 11, p. 11; J. Lachner, supra note 11; T. Ingelmann, supra note 14, p. 252.

45 R. Bork, "Report on Transactions Avoidance Laws (Ceril Report 2017/1)”, p. 2, available at: http://ceril.congressus.nl/_media/1296799/6d509c400baa4af081b4bda6a0326139/view [last accessed 21.5.2021]; A. Keay, "Harmonisation of avoidance rules in European Union insolvencies: the critical elements in formulating a scheme", The Northern Ireland Legal Quarterly, 2018, vol. 69, issue 2, p. 90.

${ }^{46}$ G. McCormack, A. Keay, S. Brown, J. Dahlgreen, "Study on a new approach to business failure and insolvency Comparative legal analysis of the Member States' relevant provisions and practices. Tender No. JUST/2014/JCOO/PR/CIVI/0075", 2016, p. 143, available at: https://ec.europa.eu/info/sites/info/files/insolvency_study_2016_final_ en.pdf [last accessed 21.5.2021].

\footnotetext{
${ }^{47}$ Ibid., p. 143-144.

${ }^{48}$ Ibid., p. 144.

49 Ibid., p. 159.
} 
rules that especially provide for the invalidation of security in certain conditions. This group of rules includes rights in rem. ${ }^{50}$

In consequence of an application to the rights in rem rules on voidness, voidability, or unenforceability it is possible to protect creditors. The debtor or third party cannot take benefits from rules stipulated in article 8(1) of the recast EIR when the detrimental legal act was made. The creditor's secured rights in rem do not enjoy unlimited protection. ${ }^{51}$

\section{UnCITRAL LeGISLATIVE GUIDE ON INSOLVENCY LAW}

Not only legal acts provide regulation on rights in rem during insolvency proceedings, but this issue is raised also in soft law, namely in the Legislative Guide on Insolvency Law provided by United Nation Commission on International Trade Law (UNCITRAL). ${ }^{52}$

The purpose of the Legislative Guide on Insolvency Law is to assist the establishment of an efficient and effective legal framework to address the financial difficulty of debtors. It is intended to be used as a reference by national authorities and legislative bodies when preparing new laws and regulations or reviewing the adequacy of existing laws and regulations. ${ }^{53}$ The Legislative Guide does not provide a single set of model solutions to address the issues central to an effective and efficient insolvency law. It helps to evaluate the different approaches available, and to choose the one most suitable in the national or local context. ${ }^{54}$

The Legislative Guide is divided into two parts. Part one of the Legislative Guide articulates broad policies and purposes common to all insolvency laws. Part two of the Legislative Guide details the core provisions for an effective and efficient insolvency law. It covers

${ }^{50}$ Ibid., p. 157.

51 T. Ingelmann, supra note 14, p. 252.

52 UNCITRAL Legislative Guide on Insolvency Law, 2005, pp. 1-400, available at: https://uncitral.un.org/sites/uncitral.un.org/files/media-documents/uncitral/en/0580722_ebook.pdf [last accessed 21.5.2021], (hereafter the 'Legislative Guide').

${ }^{53}$ Ibid., p. 1.

54 Ibid., p. 2. 
topics ranging from commencement to the closing of a liquidation or reorganisation proceeding. ${ }^{55}$

When it comes to applicable law the Legislative Guide recommends that in principle, the lex fori concursus, namely, the law of the state where the insolvency proceeding is commenced, should apply to the effects of the insolvency proceedings on the rights and claims. ${ }^{56}$

Nevertheless, the Legislative Guide illustrates certain exceptions to the principle of lex fori concursus. Including security interests, labour contracts and avoidance provisions, etc. Undoubtedly, the treatment of secured claims is the most essential exception. Whether and to what extent the effect of the insolvency proceeding of a state extends to the collateral located outside of that state is a crucial issue in cross-border insolvency. ${ }^{57}$

As was pointed out in the Legislative Guide, some insolvency laws also adopt the approach of providing an exception to the application of the lex fori concursus with respect to security interests. This solution means that the law governing a right in rem would determine not only its creation and general validity, but also its effectiveness in the case of insolvency proceedings. It means that the position of the real security interest in insolvency proceedings commenced abroad will not be established by the lex fori concursus. In that case the insolvency rules of the law applicable to the security interest will be appropriate. ${ }^{58}$

The Legislative Guide outlines the purpose of legislative provisions on carve-out from the lex fori concursus. The purpose of the provisions on the applicable law in insolvency proceedings is inter alia to establish the law applicable in insolvency proceedings and exceptions, if any, to the application of that law. ${ }^{59}$ When it comes to contents of legislative provisions any exceptions should be limited in number and be clearly set forth or noted in the insolvency law. ${ }^{60}$

55 S. Block-Lieb, T. Halliday, "Harmonization and Modernization in UNCITRAL's Legislative Guide on Insolvency Law", Texas International Law Journal, 2007, vol. 42, p. 498.

${ }_{56}$ M. Han, "Model Law or Convention on Selected International Insolvency Issues", p. 2, available at: https://uncitral.un.org/sites/uncitral.un.org/files/media-documents/ uncitral/en/a2_convention_4_han.pdf [last accessed 21.5.2021].

57 Ibid., p. 3.

58 UNCITRAL Legislative Guide on Insolvency Law, supra note 52, p. 71.

59 Ibid., p. 72.

${ }^{60}$ Ibid., p. 74. 


\section{CONCLUSIONS}

The conclusions from the comparisons of two legal acts are as follows.

Firstly, both legal acts, the EU regulations, and the Legislative Guide take as a principle the application of the law of the State of opening of insolvency proceedings as the law applicable to the effects of such proceedings. The application of a law other than the law of the State in which the insolvency proceedings are opened is an exception. Moreover, the Legislative Guide among the possible exceptions from the lex fori concursus points to rights in rem. It means that the EU framework complies with the rules provided in the international act.

Secondly, EU regulations are binding law while the Legislative Guide is a soft law. For that reason EU regulations provide extensive regulation on rights in rem, whereas the Legislative Guide delivers some general remarks on constructions of provision. The reason for that is that the EU regulations provide a legal framework for insolvency proceedings. There is a need to address specific issues and do it in precise way. On the other hand, the purpose of the Legislative Guide is different. That document provides a general overview of possible solutions to issues concerned with insolvency. It contains recommendations on the content of the regulations, but does not provide binding solutions by itself.

Thirdly, EU regulations comply with the recommendations provided in the Legislative Guide on contents of legislative provisions. There are two recommendations relating to that matter. Namely, there is need to clearly set forth the exceptions and limit them in number. The exception from the lex fori concursus is expressly provided in the recast EIR. It is strictly limited to rights in rem. Although owing to the lack of definition there are doubts on the qualification of rights as rights in rem, it is a problem of the interpretation of a legal act. But it is not the issue of a lack of regulation. By the same token, the problem of the legal nature of article 8 of the recast EIR can be solved. There are legal provisions concerning the exception from the lex fori concursus. In fact there are different approaches to the understanding of legal terms. But it does not mean that there is no regulation. 
Fourthly, the decision on the different treatment of creditors and third parties' secured by rights in rem results from economic reasons. The regulation is an unique legal solution adapted to improve the internal market. 